\title{
Effects of Dialogic, Peer and Teacher - Guided Discourse Patterns on Students' Interest in Biology in Yola Education Zone of Adamawa State
}

\author{
O. R. Ugwuadu, Ph.D \\ Department Of Science Education Modibbo Adama University Of Technology, P.M.B 2076, Yola. \\ Adamawa State, Nigeria.
}

\begin{abstract}
This study determined the effects of dialogic, peer and teacher - guided discourse patterns on students' interest in biology. The study also determined the influence of the discourse patterns on male and female students' interest in biology. Two research questions and four null hypotheses tested at 0.05 level of significance guided the study. The design of the study was quasi - experimental of non-equivalent comparative group design. A sample of 164 SSII students (94 males and 70 females) from three intact classes in Yola education zone of Adamawa State participated in the study. The three intact classes were drawn from three secondary schools selected through purposive sampling technique. Discourse pattern were randomly assigned to intact classes in the sampled schools. The main instrument used for data collection was a Biology Interest Scale (BIS) which was both face and construct validated. The internal reliability coefficient of BIS was 0.84 established with cronbach alpha method. The coefficient of stability was 0.75 and 0.75 for the first and second administration of the test respectively determined with test - retest method and calculated using Pearson product moment correlation method. Mean and standard deviation were used to answer the research questions while ANCOVA was used to test the hypotheses. Result of the study shows that the three discourse patterns enhanced students' interest in biology. There is no significant difference in the mean interest scores of students tanght biology using the three discourse patterns and likewise there is no significant difference in the mean interest score of male and female students taught the biology topics using the three discourse patterns. It was recommended among others that the three discourse patterns be used for effective teaching of biology in Secondary Schools.
\end{abstract}

\section{Introduction}

Discourse pattern is a talk pattern used to pass information to people. (Sadler 2006), and Viiri and Saari (2006) defined discourse as verbal expression or conversation, talk, or speech. In teaching-learning process, discourse pattern is a way teachers and students converse, talk and express themselves verbally during classroom activities. The implication is that teachers and students use discourse patterns in classroom interactions (Ugwuadu, 2011). Krat and Kratcoski (2004) viewed that the discourse and interactions that occur in classrooms form a communicative context for learning. This may however, depend on clarity of message and effective use with teaching methods.

Being a talk pattern, the discourse patterns of teachers and students may be of benefit in improving students' interest in biology (science of life) since literature revealed that teachers do not use much of discourse patterns in classroom activities (Viiri \& Saari, 2006). Interest is a powerful source of human motivation which is capable of arousing and sustaining concentrated effort (Bhatia, 2003). It is a disposition which prompts a person to spontaneous activity e.g. paying attention to school work or any other activity (Dandekar \& Makhiji, 2002). $\mathrm{Njoku}(2003)$ opined that interest is a response to liking or disliking of an event, activity, object or person. There are the expressed interest which is a verbal declaration of like or dislike, manifest interest which involves professing interest in an activity, tested interest which is interest as measured by objective test and inventoried interest which refers to an individual's performance on a large number of activities listed on an interest inventory (Balogun, 2005). Tobias (1995) opined that adapting instructionsto students' interest may have a positive motivational value for a long period of time which may facilitate students' recall of learned materials.

Literature has however, revealed that students' interest in biology is low because many students especially females perceive many topics in biology as difficult and confusing Olagunju (2001). In view of the foregoing, discourse patterns being useful in classroom activities were employed along with inquiry method, an innovative method to determine whether they could improve the persistent low interest of male and female students in biology. The researcher contended that if the students' interests improve, the strategy of using discourse pattern and inquiry method in teaching biologycould be extendedto other subjectsand other innovative methods. This is because the use of inquiry method was significantly better than the expository method in enhancing cognitive achievement in biology for all levels of scientific literacy students (Nwagbo, 2001). Discourse pattern and 
teachers' methodology are not the same but they are related because discourse pattern is used to implement teaching methodology like lecture, demonstration method etc in the classroom. Both the teaching method and discourse patternsare used simultaneously and never in isolation during classroom instruction delivery.

Three biology topics and three discourse patterns namely: dialogic, peer and teacher - guided were-studied in this paper. The biology topics are: ecological succession, overcrowding and food shortage taken from the National Curriculum for Senior Secondary, year Two (2008). The topics were chosen not only that they are perceived as difficult and confusing by students they are also either hurriedly taught or not taught at all by teachers (Okeke\&Ochuba, 2006). The use of the different discourse patterns as main effects in this study may enhance the understanding of the difficult topics.

Each of the discourse patterns has its unique characteristics that foster learning. The dialogic discourse pattern is democratic because it involves free dialogue between the teacher and his students during classroom activities (Aggrawal, 2002). In addition teacher rewards meaningful contributions through praises and encouragement (Viiri\&Saari, 2006). Udeani(1992) found out that teacher dominated classrooms do not offer any higher premium to integrated science students as do the democratic and participatory interaction patterns.

The peer discourse pattern is a cooperative learning strategy in which students work collaboratively with their classmates in small groups to solve a common problem (Okebukola, 2004). Lee (2000) found out that only II out of 42 learners spoke during a question and answer discussion in a teacher-fronted discussion while 46 out of 46 spoke during group discussion among students showing the effectiveness of peer discourse pattern in teaching and learning.

In the teacher - guided discourse patternthe teacher directs and guides the students in a classroom talk on a specific problem which may help to increase students' interest in a lesson (Viiri\&Saari, 2006).Ugwuadu and Obi (2009) isolated food web, community and ecosystem topics in ecology as difficult topics to students.Okeke (2001) reported that there was total lack of interest of students in ecology in secondary schools. Ugwuadu (2011) found out that students taught biology using the dialogic, peer and teacher - guided discourse patterns did not differ significantly from one another in their interest; there is no significant difference in the mean interest scores of male and female students taught biology with each of the three discourse patterns.

The problem of this study is: what would be the effects of the three discourse patterns namely dialogic, peer and teacher - guided discourse patterns on students' interest in biology when taught with inquiry method? Would the use of the different discourse patterns have influence on interest of male and female biology students?

The general purpose of this study was to investigate the effects of dialogic, peer and teacher - guided discourse patterns on students' interest in biology when taught with inquiry method. Specifically, the study determined:

1. the effects of dialogic, peer and teacher - guided discourse pattern on students' interest in biology.

2. the effects of the three discourse pattern on male and female students' interest in biology.

\section{Research Questions:}

This study was guided by the following research questions:

1. What are the mean interest scores of students taught the biology topics using the dialogic, peer and teacher - guided discourse patterns?

2. What are the mean interest scores of male and female students taught the biology topics using the dialogic, peer and teacher - guided discourse patterns?

\section{Hypotheses}

The following null hypotheses were posed to guide the study and tested at 0.05 level of significance.

$\mathrm{Ho}_{1}$ : There is no significant difference in the mean interest scores of students taught the biology topics using the three discourse patterns.

$\mathrm{HO}_{2}$ : There is no significant difference in the mean interest scores of male and female students taught the biology topicsusing the dialogic discourse pattern.

$\mathrm{HO}_{3}$ : There is no significant difference of mean interest scores of male and female students taught the biology topics usingthe peer discourse pattern

$\mathrm{HO}_{4}$ : There is no significant difference themean interest scores of male and female students taught the biology topics using the teacher - guideddiscoursepattern.

\section{Research Method}

The research design adopted for the study was quasi - experimental of non-equivalent comparative group design. The design was adopted because subjects were not randomly assigned to groups instead intact classes were randomly assigned to experimental groups. 
The study was carried out in Yola education zone of Adamawa State. The zone was used because the zone has the highest number of co-educational schools, soa good representative sample would be obtained from there.

The population of the study consisted of all senior secondary two (SSII) biology students numbering 6, 588 in 16 co-educational schools. SSII students were used because the topic of the study fell under the SSII biology curriculum. Co-educational schools were usedbecause the researcher wanted to find out if the different discourse patterns would have any influence on the interest of male and female students in the same class and school, using the biology topics of the study.

The sample of the study was 164 biology students (94 males and 70 females) selected from three different schools by purposive sampling technique. Purposive sampling technique was used because the schools met the research purpose. One intact class of SSII was randomly selected from four classes in each school. Discourse patterns were randomly assigned to the three intact classes.

The main instrument used for data collection was a Biology Interest Scale '(BIS) which was constructed by the researcher. The BIS contained 40 items developed on four - point scale which the respondents were required to respond by ticking their degree of agreement or disagreement to the items. The 40 items consisted of 20 positive and 20 negative statements which were scored as follows: strongly agree $=4$, agree $=3$, disagree $=2$, and strongly disagree $=1$ for positive statements. The scoring was reversed for negative statements as follows: strongly agree $=1$, agree $=2$, disagree $=3$, strongly disagree $=4$.

The draft BIS was given to four experts in Science Education (Biology) and Educational Measurement and Evaluation for face and construct validation. The validators were required to assess the instrument in terms of clarity of expression and suitability of the items (face validation). After face validation, five items that were ambiguous were dropped and the remaining 35 items were subjected to construct validation by using factor analysis to compute the factor loading. Trial testing was carried out in one school outside the ones used for the study in order to collect data for the factor analysis. Items were selected for use if they were factorial pure by having high loading on one factor only and secondly if the item had a factor loading of 0.30 and above (Nworgu, 2006). At last, 30 items were selected and five items were rejected for not meeting the criteria set for selection.

The selected 30 items were trial - tested and the result was used to calculate the reliability coefficient using Cronbach alpha method which gave an internal consistency reliability coefficient of 0.84 on SPSS computer software. The coefficient of stability of the instrument was 0.75 and 0.75 for first and second administration of the test respectively calculated using the Pearson product moment correlation method. The tests were administered with an interval of two weeks.

\section{Treatment Procedure}

The main teaching method used for the study was inquiry method. Each intact class was differentiated by the discourse pattern randomly assigned to it which the regular biology teachers that served as research assistants used in teaching the groups. The reason for teaching one discourse pattern in one school was to avoid contamination of treatment if one school was used for all the treatments. All the research assistants were trained in their respective discourse patterns by the researcher. On the first day of the experiment, the BIS was administered as pre-test on each of the groups in the three schools. The groups were later taught the biology topics used for the study by the trained research assistants. The treatment lasted for four weeks and the last period of the fourth week was used for administering post-test. Some extraneous variables like Hawthorne effect, teacher variable, initial group difference, etc were controlled to prevent them from affecting the study.

\section{Method of Data Analysis}

Mean and standard deviation were used to answer the research questions while Analysis of co-variance (ANCOVA) was used to test the hypotheses. The total or overall mean interest score of the respondents was computed and used for answering the research questions. Total mean interest score below 2.50 relative to the four point scale was regarded as low interest while mean interest score of 2.50 and above was interpreted as high interest. ANCOVA was used to test the hypotheses.ANCOVA was used because apart from controlling the initial differences across the groups, it was also used as post-hoc control.

\section{Results}

The results were presented in tables according to research questions and hypotheses after statistical analysis of collected data as shown in Tables below:

\section{Research Question 1}

What is the mean interest scores of students taught the biology topics using the dialogic, peer and teacher - guided discourse method? 
Table 1: Mean interest scores and standard deviation of students taught the biology topics using the three discourse pattern.

\begin{tabular}{|c|c|c|c|c|}
\hline Experimental Groups & & Pr. Interest & $\begin{array}{l}\text { Post } \\
\text { Interest }\end{array}$ & $\begin{array}{l}\text { Mean gain } \\
\text { score }\end{array}$ \\
\hline Dialogic discourse pattern & $\begin{array}{l}\text { Mean } \\
\mathrm{N} \\
\text { Std deviation }\end{array}$ & $\begin{array}{l}1.89 \\
56 \\
0.652\end{array}$ & $\begin{array}{l}3.05 \\
56 \\
0.773\end{array}$ & 1.16 \\
\hline Peer discourse pattern & $\begin{array}{l}\text { Mean } \\
\mathrm{N} \\
\text { Std Deviation }\end{array}$ & $\begin{array}{l}1.89 \\
0.55 \\
0.658\end{array}$ & $\begin{array}{l}3.35 \\
55 \\
0.775\end{array}$ & 1.46 \\
\hline Teacher-guided discourse pattern & $\begin{array}{l}\text { Mean } \\
\mathrm{N} \\
\text { Std Deviation }\end{array}$ & $\begin{array}{l}1.88 \\
53 \\
0.67\end{array}$ & $\begin{array}{l}3.06 \\
53 \\
0.795\end{array}$ & 1.18 \\
\hline
\end{tabular}

Data in Table 1 show the mean interest gain scores of 1.16, 1.46 and 1.18 for students taught the biology topics using the dialogic, peer and teacher - guided discourse pattern respectively.

\section{Research Question 2:}

What is the mean interest scores of male and female students taught the biology topics using the dialogic, peer and teacher - guided discourse pattern?

Table 2: Mean interest scores and standard deviation of male and female students taught the biology topics using the three discourse patterns.

\begin{tabular}{|c|c|c|c|c|}
\hline Experimental Groups & Gender of subjects & $\mathrm{N}$ & Post Mean Score & $\begin{array}{l}\text { Standard } \\
\text { deviation }\end{array}$ \\
\hline \multirow{3}{*}{ Dialogic discourse pattern } & Males & 32 & 3.16 & .723 \\
\hline & Females & 24 & 2.92 & .830 \\
\hline & Total & 56 & 3.05 & .773 \\
\hline \multirow[t]{3}{*}{ Peer discourse pattern } & Males & 32 & 3.38 & .751 \\
\hline & Females & 23 & 3.30 & .822 \\
\hline & Total & 55 & 3.35 & .775 \\
\hline Teacher- guided discourse & Males & 30 & 3.13 & .776 \\
\hline \multirow[t]{2}{*}{ Pattern } & Females & 23 & 2.96 & .825 \\
\hline & Total & 53 & 3.06 & .795 \\
\hline \multirow[t]{3}{*}{ Total } & Males & 94 & 3.22 & .750 \\
\hline & Females & 70 & 3.06 & .832 \\
\hline & Total & 164 & 3.15 & .780 \\
\hline
\end{tabular}

Data in Table 2 indicate the mean and standard deviation of male and female students exposed to the three discourse patterns. Using the dialogic discourse pattern, males had a post interest mean score of 3.16, standard deviation of .723; females had 2.92 and standard deviation of .830. With the peer discourse, male had post interest mean score of 3.38, standard deviation of .751 while females had 3.30 standard deviation of .822. For the teacher - guided discourse pattern, males had 3.13 mean interest score, standard deviation of .776 and females scored 2.96, standard deviation of .825. Males seem to have scored higher post interest mean scores than the females using the three discourse patterns.

$\mathrm{Ho}_{1}$ : There is no significant difference in the mean interest scores of students taught the biology topics using the three discourse patterns.

Table 3: Analysis of covariance (ANCOVA) of students post mean interest score when taught the biology topics using the three discourse patterns.

\begin{tabular}{|llllll|}
\hline Source & Sum of Squares & DF & Mean Squares & F & Sig \\
\hline Corrected Model & $4.413^{\mathrm{a}}$ & 6 & .735 & 1.193 & .313 \\
Intercept & 159.160 & 1 & 159.160 & .258 .206 & .112 \\
Printerest & .069 & 1 & .069 & 2.590 & .739 \\
Experimental & 3.193 & 2 & 1.596 & .813 & .078 \\
Gender & 1.118 & 1 & 1.118 & .161 \\
Experimental gender & .198 & 2 & .099 & .852 \\
Error & 96.776 & 157 & .161 & \\
Total & 1731.000 & 164 & & \\
Corrected Total & 101.189 & 163 & & \\
\hline
\end{tabular}


Data in Table 3 indicate that students taught the three discourse patterns did not differ significantly from one another in their interest. F - value of 2.590 is significant at 0.078 but not significant at 0.05 level of probability. $\mathrm{Ho}_{1}$ is accepted.

$\mathrm{Ho}_{2}$ : There is no significant difference in the mean interest scores of male and female students taught the biology topics using dialogic discourse pattern.

Table4: Analysis of Co - variance (ANCOVA) of male and female students' post interest mean scores when taught with dialogic discourse pattern.

\begin{tabular}{|llllll|}
\hline Source & Sum of Squares & DF & Mean Squares & F & Sig \\
\hline Corrected Model & $.826^{\mathrm{a}}$ & 2 & .413 & .683 & .509 \\
Intercept & 49.422 & 1 & 49.422 & 81.820 & .000 \\
Printerest & .038 & 1 & .038 & .064 & .802 \\
Experimental & .000 & 0 & - & - & - \\
Gender & .821 & 1 & .821 & -360 & .249 \\
Experimental gender & .000 & 0 & - & - & - \\
Error & 32.014 & 53 & .604 & & \\
Total & 555.000 & 56 & & & \\
Corrected Total & 32.839 & 55 & & & \\
\hline
\end{tabular}

Data in table 4 show that there is no significant difference in the mean interest scores of male and female students taught the biology topics using the dialogic discourse pattern. This is because the calculated $\mathrm{F}-$ value of 1.360 is significant at 0.249 and not significant at 0.05 level of probability, so $\mathrm{Ho}_{2}$ is not rejected.

$\mathrm{Ho}_{3}$ : There is no significant difference in the mean interest scores of male and female students taught the biology topics using peer discourse pattern.

Table 5: Analysis of Co - variance (ANCOVA) of male and female students' post interest mean scores taught using the peer discourse pattern

\begin{tabular}{|llllll|}
\hline Source & Sum of Squares & DF & Mean Squares & F & Sig \\
\hline Corrected Model & $.070^{\mathrm{a}}$ & 2 & .035 & .056 & 99.676 \\
Intercept & 62.042 & 1 & 62.042 & .004 & .006 \\
Printerest & .003 & 1 & .003 & - & .947 \\
Experimental & .000 & 0 & - & .111 &. \\
Gender & .069 & 1 & .069 & - & -740 \\
Experimental gender & .000 & 0 & - & .622 & \\
Error & 32.367 & 52 & & \\
Total & 648.000 & 55 & & \\
Corrected Total & 32.436 & 54 & & \\
\hline
\end{tabular}

Data in table 5 indicate that there is no significant difference in the mean interest scores of male and female students taught the biology topics with peer discourse pattern. F - value calculated of 0.111 is significant at 0.740 and not significant at 0.05 level of significance, so, $\mathrm{Ho}_{3}$ is not rejected.

$\mathrm{Ho}_{4}$ : There is no significant difference in the mean interest scores of male and female students taught the biology topics using the teacher - guided discourse pattern.

Table 6: Analysis of Co-variance (ANCOVA) of male and female students post interest mean scores taught with teacher - guided discourse pattern.

\begin{tabular}{|c|c|c|c|c|c|}
\hline Source & Sum of Squares & DF & Mean Squares & $\mathbf{F}$ & Sig \\
\hline Corrected Model & $.4450^{\mathrm{a}}$ & 2 & .225 & .347 & .708 \\
\hline Intercept & 48.249 & 1 & 48.249 & 74.504 & .000 \\
\hline Printerest & .043 & 1 & .043 & .066 & 798 \\
\hline Experimental & .000 & 0 & - & - & - \\
\hline Gender & .445 & 1 & .445 & .687 & .411 \\
\hline Experimental gender & .000 & 0 & - & - & - \\
\hline Error & 32.380 & 50 & 648 & & \\
\hline Total & 528.000 & 53 & & & \\
\hline Corrected Total & 32.830 & 52 & & & \\
\hline
\end{tabular}

Data in Table 6 indicate that there is no significant difference in the mean interest scores of male and female students taught the biology topics with teacher - guided discourse pattern. F-value of 0.687 is significant at 0.411 but not at 0.05 level of probability. $\mathrm{H}_{4}$ is not rejected.

The following major findings resulted from the study:

1. Students taught the biology topics using the three discourse patterns (dialogic, peer and teacher guided) did not differ significantly from one another in their interest.

2. There is no significant difference in the mean interest scores of male and femalestudents exposed to the biology topic using each of the three discourse patterns. 
3. Gender had no influence on male and female students' interest in biology Table 3 $(\mathrm{p}>.161<0.05)$

\section{Discussion of Findings:}

Research question one on Table one and hypothesis one on Table three sought to determinethe effects of the three discourse patterns on students' interest in biology. The mean gain scores obtained were 1.16, 1.46 and 1.18 using the dialogic, peer and teacher - guided discourse patterns respectively. A test of hypothesis one showed no significant difference in the mean interest scores of the students. The result suggests that the three discourse patterns are equally effective in enhancing students' interest in biology. This is because students showed improved interest after post -test. This finding is in line with Tobias (1995) that adapting instructions to students' interest may have a positive motivational value for a long period of time which may facilitate students' recall of learned materials. In this case, the three discourse patterns being activity - oriented may have appealed to students' interest which resulted in their showing increased interest in the biology topic taught to them making them to score highly after posttest.

The result in Table 2 reveals that male students taught the biology topics using the dialogic discourse pattern had an interest mean score of 3.16, females had 2.92, but a test of hypothesis 2 (Table 4) showed that the mean interest scores had no significant difference. This result for dialogic discourse pattern is similar to that of peer and teacher - guided discourse pattern where the males had higher interest mean scores than the females (Table 2) but the results were not significant. (Tables 5 and 6). The implication is that both male and female students had equal interests in the biology topics taught to them using the different discourse patterns. These results could be attributed to the characteristics of each of the discourse patterns in fostering learning. Using the dialogic discourse pattern the findings agree with Udeani (1992) that teacher dominated classrooms do not offer any premium to Integrated Science students as do the more democratic and participatory interaction patterns. Also the result agreed with Viiri and Saari (2006) that teacher-guided discourse pattern enables students to perform betterwith the teacher directing them. The findings also agree with Lee (2000) that 11 out of 42 learners spoke during a question and answer discussion in a teacher - fronted discussion while 46 out of 46 spoke during group discussion among students showing the effectiveness of peer discourse pattern. The result is in line with Ugwuadu(2011) that the mean interest scores of male and female students exposed to the three discourse patterns was not significant.

\section{Conclusion:}

The use of the three discourse patterns (dialogic, peer and teacher - guided) in teaching biology increased students' interest in the subject. This is because there is no significant difference in the mean interest scores of the students used for the study. Female students as well as male students had equal interests in biology after post -testbecause their mean interest scores on testing the hypothesis did not show significant difference. In other words, gender had no influence in the interest of students in biology meaning that the discourse patterns can be used across gender. The persistent low interest of students especially the females in some topics in biology as literature revealed could be attributed to teachers' inability to use much of discourse patterns in teaching biology. This explanation was deduced from the fact that the post - test result was higher than the pre - test result in the biology topics used for the study which the students perceived as difficult.

\section{Recommendations}

The following recommendations are made from the findings of the study.

1. The use of the three discourse patterns in teaching biology is result - oriented so teachers should endeavor to use the discourse patterns in teaching in order to facilitate their teaching of biology.

2. The curriculum of teacher education should include the three discourse pattern so as to popularize the topics.

\section{References}

[1]. Aggrawal, J. C. (2002). Essentials of Educational Technology Teaching - Learning Innovations in Education Delhi: Vikes Publishing House PVT Ltd.

[2]. Balogun, T. A (1985). Interest - Science and Technology Education in Nigeria. Journal of the Science Teachers' Association of Nigeria, $23(1 \times 2) 92-99$.

[3]. Bhatia, H. R. (2003). A Textbook of Educational Psychology New - Delhi: RajiV - Ben Publishers, Ltd.

[4]. Dandekar, W. N Makhiji, S. M. (2002) Psychological Foundations of Education New Delhi: Rajv- Ben Publishers Ltd.

[5]. Federal Government of Nigeria (2008) National Curriculum for Seniorsecondary Schools, Federal Government Printing Press, Vol. 3: Science.

[6]. Krat, K. B \&Kratcoski, A. (2004).Teacher - studentinteractions in a ubiquitouscomputing learning within dyads \& triads of interactions Journal of the Research Centre for Educational Technology, 1 (1), 306 - 410.

[7]. Lee, J. F. (2000). Tasks and Communicating in language classroom. New York: McGraw Hill Publishers, Ltd.

[8]. Njoku, Z. C. (2003).Development and Preliminary validation of a scale for the Assessment of Students' Interest in O' Level Practical Chemistry, Journal of the Science Teachers' Association of Nigeria. 38 (1 \& 2)64 - 70.

[9]. Nworgu, B. G. (2006) Educational Research: Basic Issues andmethodology (2nd Ed.) Nsukka: University Trust Publishers. 
[10]. Okeke, EAC (2001) Evaluating High School Biology Journal of Science Teachers Association of Nigeria, $19(2) .69$ - 79.

[11]. Okebukola, P. A (1984) Tackling the problem of large classes in biology: An investigation into the effects of a cooperative teaching technique, Journal of Science Teachers' Association of Nigeria 22(2)73- 76.

[12]. Olagunju, A.M (2001) increasing girls' interest, participation and achievement in science, proceedings of $42^{\text {nd }}$ annual conference of science 2004 Teachers' association of Nigeria, Heinemann Educational Books (Nig) Ltd.

[13]. Sadler, T. D. (2006). Promoting discourse and argumentation 'in Science, Journal of science Teacher Education, 17,323 - 346.

[14]. Tobias, S. (1995) Interest and Meta-cognitive word knowledge, Journal of Educational Psychology, 87 (3), 399 - 405.

[15]. Udeani, U. N (1992). Learning outcomes in Integrated Science as Related to Teacher and student characteristics and classroom interaction pattern, Unpublished $\mathrm{PhD}$ Thesis, University of Nigeria, Nsukka.

[16]. Ugwuadu, O. R. \& Obi, C. I. (2009) Isolating topics of High Perceived difficulty in Secondary School Biology in Adamawa State.Journal of Educational Studies, 14(2); 172 - 187.

[17]. Ugwuadu, O. R. (2011). Effects of Discourse Patterns on Students' Achievement and Interest in Biology Unpublished Ph. D Thesis, University of Nigeria, Nsukka.

[18]. Viiri, J \&Saari, H (2006). Teacher Talk Patterns in Science Lessons: Use in Teacher Education, Journal of Science Teacher Education, 17,347 - 365 . 